Papers and Proceedings of the Royal Society of Tasmania, Volume 110, 1976.

(ms, received 20.4.1975)

\title{
STRUCTURE AND METAMORPHISM OF THE MC PARTLAN PASS - SENTINELS AREA
}

\author{
by S.J. Williams \\ Geological Survey of Western Australia, formerly \\ Geology Department, University of Tasmania
}

(with one table, four text-figures and four plates)

\section{ABSTRACT}

Low metamorphic grade Precambrian quartzites and phyllites of the Mc. Partlan Pass - Sentinels area have been subjected to polyphase deformation and polyphase met. amorphism. The earliest recognizable folds are tight to isoclinal and they have a penetrative foliation, with syntectonic mineral growth parallel to their axial surface. $F_{2}$ folds, which are also tight to isoclinal and nearly coplanar with $F_{1}$, have an associated $S_{2}$ crenulation cleavage, with syntectonic mineral growth. The dominant folds in this area are of the third generation and they control the orientation of earlier structures. $\mathrm{F}_{3}$ are tight to close, upright folds in phyllites, and are of more open style in quartzites. They have a moderate to steep north-westerly plunge. The $S_{3}$ cleavage may be a crenulation cleavage, a fracture cleavage, or a more isotropic foliation. $D_{4}$ structures occur sporadically throughout the area. Events $\mathrm{D}_{1}$ to $\mathrm{D}_{4}$ are of probable Precambrian age. The latest structures include two distinct sets of kink bands, which may have been produced during a Palaeozoic orogeny.

\section{INTRODUCTION}

This report is a summary of a B.Sc. Honours thesis submitted to the Geology Department, University of Tasmania in 1973. The aim of this work was to establish a structural and metamorphic sequence within complexly folded quartzites and phyllites in the Mc. Partlan Pass - Sentinels area of south-western Tasmania. The area under consideration is bounded by: longitude $146^{\circ} 09^{\prime} \mathrm{E}$ and $146^{\circ} 15^{\prime} \mathrm{E}$ and latitude $42^{\circ} 50^{\prime} \mathrm{S}$ and $42^{\circ} 54 \mathrm{~S}$. Convenient access is provided by the Gordon River Road.

The area is mountainous with steep, sharp ridges separated by V-shaped valleys, or wide, flat, marshes. The morphology is directly related to the susceptibility of the underlying rocks to weathering and erosion. Topographic highs are formed in quartzites and topographic lows are in phyllite and micaceous quartzite. Poor outcrop of the latter rock types largely restricts their study to road cuttings.

The notation used herein to describe structures, or events and their temporal relationship is: $D_{n}$ refers to deformation event $n ; F_{n}$ indicates folds associated with event $D_{n}$; and $S_{n}$ and $L_{n}$ refer, respectively, to any surface, or lineation, related to $D_{n}$. $\quad S_{o}$ denotes the original bedding surface.

\section{ROCK TYPES}

The Precambrian metamorphic assemblage has been broadly divided into four major rock types: quartzites, micaceous quartzites: phyllites and a metaconglomerate unit. Two main types of quartzites can be distinguished. The first is a well-1ayered coarse-to medium-grained, saccharoidal orthoquartzite, which occurs in relatively thick units (approximately 500 metres) on the northern and western flanks of the Sentinels. The other is a flaggy, laminated variety which occurs in thinner units (maximum thickness about 30 metres) and crops out on the tops and flanks of the ridges north and south of Mc. Partian Pass.

The micaceous quartzites are composed dominantly of quartz with varying amounts 
of muscovite $(5 \%-30 \%)$ and locally chlorite as a minor component. They grade into purer quartzite at one extreme and into phyllite at the other extreme. The phyllites are mica rich, fine-to very fine-grained, grey to black, or light green rocks. They are extremely fissile. Some varieties are graphitic.

The metaconglomerate unit consist of a sequence of poorly-sorted metaconglomerates, micaceous quartzites and phyllites, which may contain pebbly bands and isolated pebbles. They occupy an area to the immediate north of the Sentinels (fig. 1) Their contact with the quartzite and micaceous quartzite of the Sentine1s is not exposed, and is an uncomformity.

\section{FIRST GENERATION STRUCTURES}

F 1 Folds

The earliest recognizable structures in the area include folds with an earlier form surface, which in some cases can be shown to be bedding $\left(S_{0}\right)$, from the presence of folded cross-bedding, and elsewhere is assumed to be $S_{O}$. Minor fold closures of the first generation are not commonly observed in the area as a whole. They are most easily recognized in purer quartzites, where overprinting by later structures is minimal. First folds are usually moderately to steeply inclined and the trend of their axial surface is dominant1y controlled by major folds of the third generation. The plunge of $F_{1}$ hinges is highly variable, due to the combined effects of several phases of deformation. However, they commonly plunge moderate to steep SW.

F1 folds are tight to isoclina1. Thicker psamitic layers have rounded hinge zones and are often flattened parallel in style. Thinner units have greater thickening in the hinge zone. In a folded sequence of layers with variable thickness there is usually a disharmonic relationship between the layers, with the thinner 1ayers being more complexly folded. Where there is a considerable competence difference between folded layers, the limbs of the more competent layers are often attenuated, leading to boudinage.

Analysis of the vergence of minor $F_{1}$ has revealed on $1 y$ one major $F_{1}$ closure in the area, which occurs at the eastern end of the Sentine1s. However, studies of this kind are hampered by the fact that minor $F_{1}$ folds are usually 1 ong-1imbed isoclines, which give no indication of vergence, and other unrecognized major closures may be present.

The $S_{1}$ Foliation

$S_{1}$ is an axial surface foliation to folds of the first generation. It is well developed throughout the area, except in the thick quartzite units of the Sentinels, where it only occurs sporadically. The $S_{1}$ foliation is parallel to the boundaries between major lithological units and is probably parallel to the original bedding. However, $S_{1}$ is not a "bedding-foliation" as can be demonstrated by local survivals of folded and disrupted fragments of earlier layers $\left(S_{0}\right)$. The near parallelism of $S_{1}$ and $S_{0}$ is due to the isoclinal nature of $F_{1}$ folds.

The expression of $S_{1}$ varies for different rock types. In flaggy laminated quartzites $S_{1}$ metamorphically differentiated layering consists of layers rich in quartz ( $1 \mathrm{~mm}$ ro $4 \mathrm{~mm}$ thick) separated by thin films of mica. In micaceous quartzites the differentiated mica layers are thicker (up to $4 \mathrm{~mm}$ thick). Quartz-rich layers have a well developed mortar texture (plate la). In phyllites $S_{1}$ is a very penetrative siaty cleavage in which individual differentiated layers are not visible in hand specimen. The foliation is defined by the strong preferred alignment of tiny, interwoven mica flakes and fibres, with small, thin, elongate lenses and ribbons of quartz. 


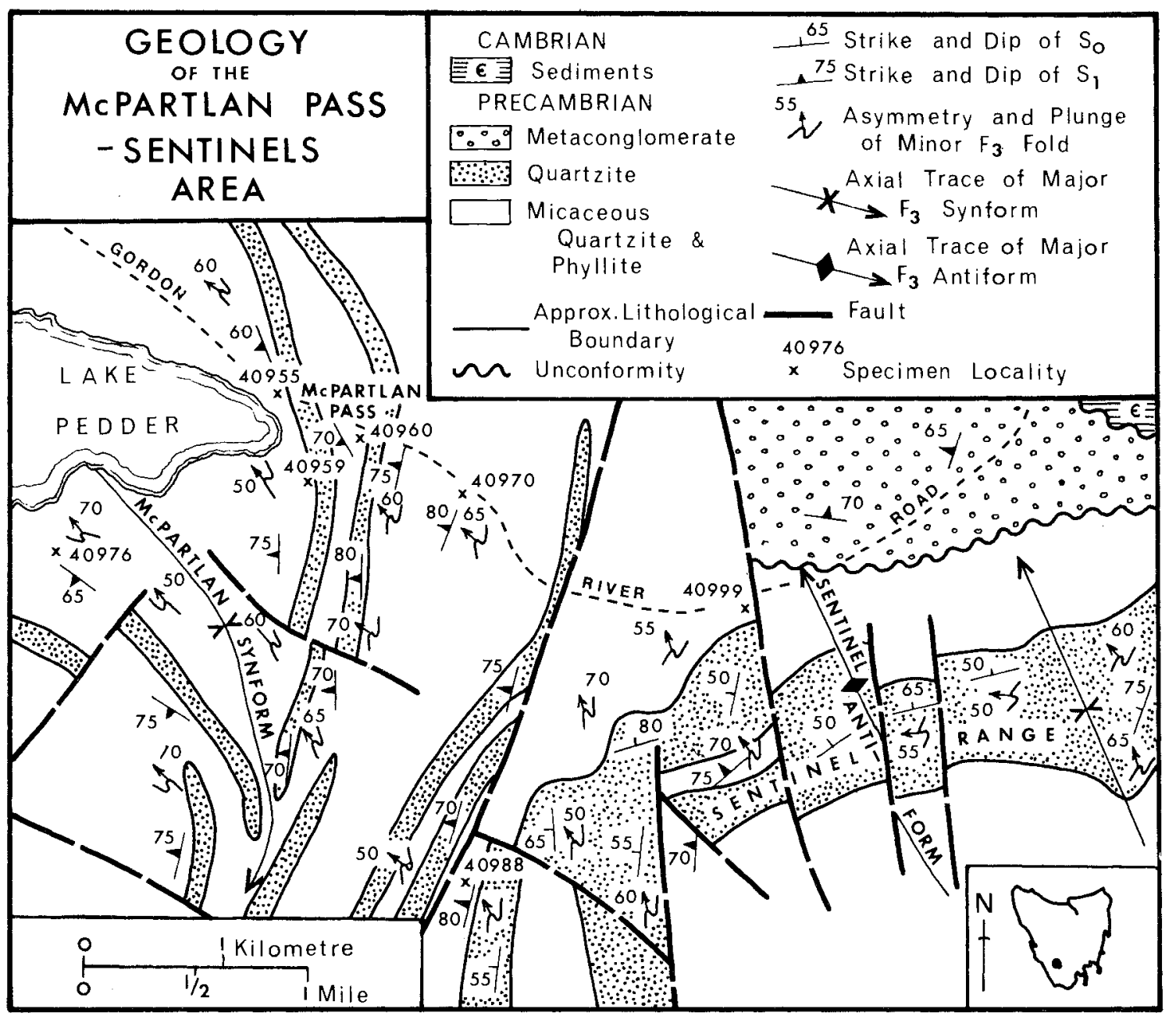

FIG. 1.- Rock types and structural elements of the McPartlan Pass - Sentinels area.

Progressive development of $\mathrm{S}_{1}$ in quartzites

In the less deformed orthoquartzites of the Sentinels the $s$ surface, or later foliations, may be entirely absent. In this case the original sedimentary fabric, consisting of nearly spheroidal well-rounded, interpenetrating quartz grains with authigenic quartz overgrowths, is preserved intact. Deformation of this fabric dur- 
ing $D_{1}$ produced elongate ellipsoidal quartz grains the dimensional preferred orientation of which defines $S_{1}$. At this early stage of foliation development, the quartz grains are invariably undulose, they are commonly fractured and are occasionally disrupted. However, unlike the quartzites in which $S_{1}$ is intensely developed, these quartz grains show little or no granulation. Also, despite elongation of the grains, the authigenic quartz overgrowths are still preserved. Where $\mathrm{S}_{1}$ is observable as a weak foliation microscopically, it is not usually visible in hand-specimen, even if a weak mica foliation is present. The slightly elongate quartz grains may be wrapped by a thin mica film, but at this stage the mica foliation is only coarsely anastomosing. As the quartz grains become more elongate the mica films become more finely anastomosing so that eventually they do define a good mesoscopic foliation.

In quartzites, of the same composition, from the ridges south of Mc. Partlan Pass the continuing sequence of progressively more intense $\mathrm{S}_{1}$ development can be $t$ raced. The quartz grains become more elongate with strong undulosity and often deformation 1 amellae are present. They develop small "beards" of fibrous quartz, as well as granulated grain margins and a more disrupted appearance (plate 1). As $\mathrm{S}_{1}$ becomes more intense in development the older grains are almost completely broken down and

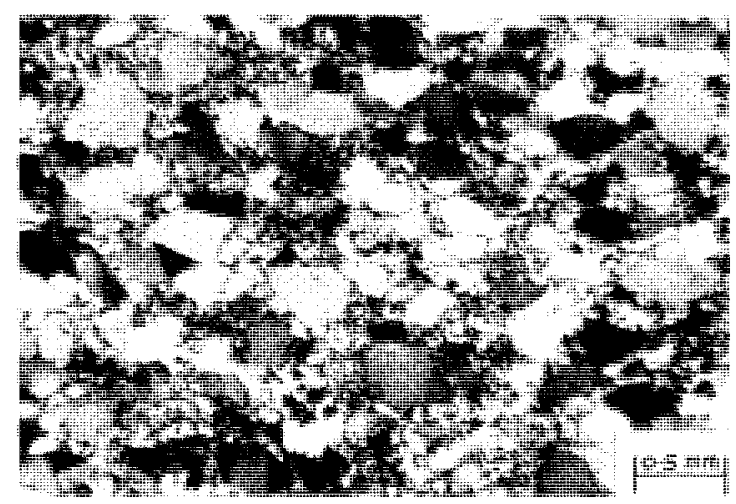

PLATE 1.- Quartzite with moderate $S_{1}$ development. The elongate quartz grains have sutured and granulated margins and fibrous quartz beards. They are surounded by fine-grained, granulated quartz. consist of isolated, highly deformed remnants set in matrix of finer-grained, granulated, re-crystallized quartz (plate 2). Thus the progressive development of $S_{1}$ in quartzites involves the conversion of a saccharoidal texture into a mortar texture.

\section{SECOND GENERATION STRUCTURES}

Folds of the second generation are tight to isoclinal. They have many features in common with $\mathrm{F}_{1}$ folds and are often difficult to distinguish from the latter in the field. Minor $\mathrm{F}_{2}$ closures are somewhat sporadic in occurrence, but they are locally abundant around Mc.Partlan Pass. In phyllites $\mathrm{F}_{2}$ closures are often obscured by an intense generated $\mathrm{S}_{2}$ surface, and by over-printing of later cleavages, mainly $\mathrm{S}_{3}$. Since their orientation depends ${ }^{3}$ on third and later generation folds, $F_{2}$ folds can be up-
xial surfaces vary in strike from WNW right, steeply inclined, or reclined and their axial surfaces vary in strike from WNW
to NNE with corresponding southerly to westerly dips. F $F_{2}$ hinges are also variable in to NNE with corresponding southerly to westerly dips. $\mathrm{F}_{2}$ hinges are also variable in
orientation, but they commonly plunge steeply to moderately WSW. Minor second folds do not usually give any sense of vergence, but where this is present they are, in all cases, asymmetric folds with an "S profile when viewed to the WSW down the axis. No major $F_{2}$ closures have been found in the area mapped.

In quartzites $F_{2}$ folds are distinguished from $F_{1}$ by microscopic analysis of the hinge area. Second folds have a penetrative, lenticular $S_{1}$ foliation as their form surface and this may be partially, or totally obliterated by a fairly penetrative, generated $S_{2}$ foliation, which cuts across $S_{1}$ at a high angle in the fold core. In phyllites and micaceous quartzites $F_{2}$ folds have a generated $S_{2}$ crenulation cleavage, which is at high angle to $\mathrm{S}_{1}$ in the $\mathrm{F}_{2}$ fold core (plate 3 ). Away from $\mathrm{F}_{2}$ core zones, the $S_{2}$ surface can be observed as a spaced $(1 \mathrm{~mm}$ to $1 \mathrm{~cm})$ crenulation cleavage, at a low ang $1 \mathrm{e}\left(15^{\circ}\right.$ to $\left.20^{\circ}\right)$ oblique to $S_{1}$. This produces a characteristic lenticular, diamond 
pattern in the rocks. However, in most phyllites, and in some micaceous quartzites, $S_{2}$ has been refracted into near alignment with $S_{1}$ and merely serves to accentuate the earlier penetrative foliation.

Lineations produced during $\mathrm{D}_{2}$ include an $\mathrm{L}_{2}$ crumple lineation, associated with $S_{2}$ crenulations, and an intersection lineation between $S_{1}$ and $S_{2}$. $L_{2}$ lineations are usually parallel to local $F_{2}$ hinges. These lineations are invarably cross-cut by a later, fine, crumple 1 ineation $\left(\mathrm{L}_{3}\right)$. Micas which grow along the $S_{2}$ foliation surface are often crenulated or crinkled by the later $S_{3}$ cleavage (plate 3).

\section{THIRD GENERATIION STRUCTURES}

$\mathrm{F}_{3}$ Folds

The third deformation event produced the dominant folds of this area. These folds exist on a11 scales, from microscopic crenulation

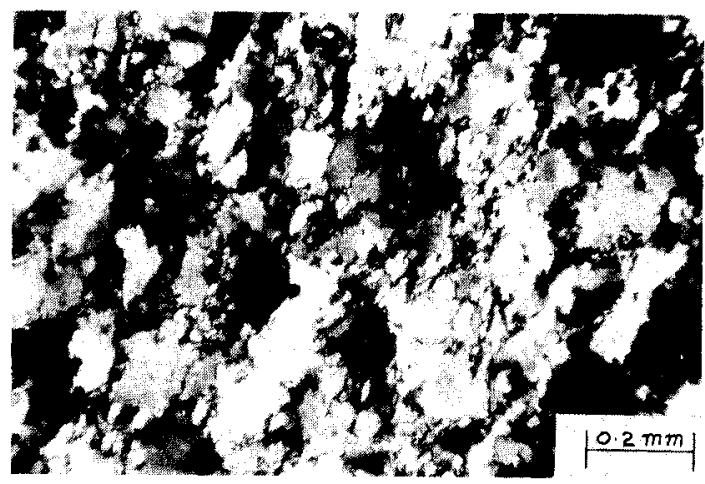

PLATE 2. - Strongly annealed quartz grains in a quartzite with an intense $S_{1}$ foliation developed.

up to macroscopic folds hundreds of metres in wavelength, and they control the orientation of the earlier surfaces, $S_{0}, S_{1}$ and $S_{2}$. Both $F_{1}$ and $F_{2}$ folds have been refolded by $\mathrm{F}_{3}$ and the superposed interference patterns are Type 3 of Ramsay (1962).

PLATE 3.- Differentiated $S_{2}$ crenulation cleavage from an $F_{2}$ fold core in phyllite. Twisted relics of $\mathrm{S}_{1}$ exist between bands of $S_{2}$ mica. The latter have in turn been deformed by the development of $\mathrm{S}_{3}$ crenulations.

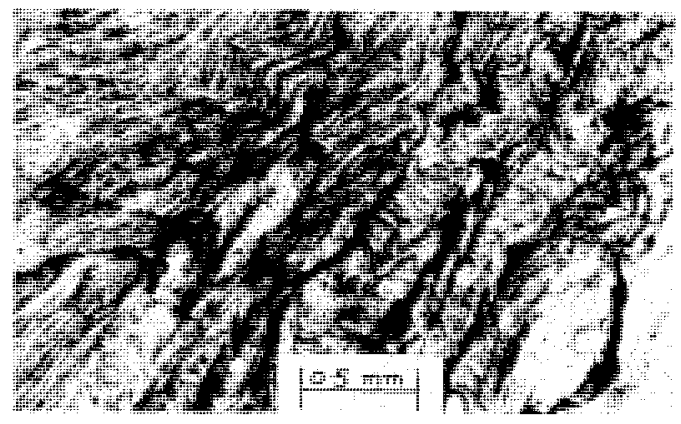

Minor $\mathrm{F}_{3}$ folds are generally steeply inclined to upright, with axial surfaces that strike NW and dip steeply SW. Their hinges usually plunge moderately to steep$1 \mathrm{y}$ Wilw. The fold style is largely governed by 1ithology. In the wel1-1aminated micaceous quartzites minor $\mathrm{F}_{3}$ folds are often kink like, open to tight folds, with rounded, and sometimes angular, hinge zones. In the more competent, thickly-layered quartzites $\mathrm{F}_{3}$ folds are usually open, parallel in style, except in areas of more intense deformation, such as the eastern end of the Sentinels, where they commonly have a flattened parallel profile. Where quartzite is inter-layered with less competent pelitic layers, the overall geometry is that of similar folds.

Folds of the types described above have been reported by Powell (1969) from the Gordon River Damsite, Bowen and Maclean (1971) from the Davey River and Boulter (1974) from the Frankland and Wilmot Ranges. Powel1, Bowen and Maclean regard them as second generation structures, but Boulter and the present author regard them as third generation structures.

By analysis of the vergence of minor asymmetric $\mathrm{F}_{3}$ folds (fig. 1) two major, third fold closures, each of which is composed of folds of various orders, have been determ- 
ined. These are the Mc. Partlan Synform (statistical axis $77^{\circ}$ to $260^{\circ}$ ) and the Sentinels Antiform (statistical axis $70^{\circ}$ to $331^{\circ}$ ). Contoured stereoplots for each of these structures are given in figures $2 \mathrm{a}$ and $2 \mathrm{~b}$. Both 'major folds are more or less cylindrical and the difference in their statistical axes may be due to rotation about a major fault which separates them. Despite the overall near cylindrical nature of the major third folds, some minor $\mathrm{F}_{3}$ folds show marked variability of plunge.

\section{$\mathrm{S}_{3}$ Cleavage}

Associated with third folds is an axial surfaces cleavage, $S_{3}$, which varies in type according to: the rock type; the nature of the pre-existing surface; and the amount of local strain. In the quartzites of the Sentinels $S_{3}$ is often the first foliation to affect the original bedding, and its development varies from a weak, to fairly penetrative, lenticular foliation, or in some cases a distinct, spaced (lcm to

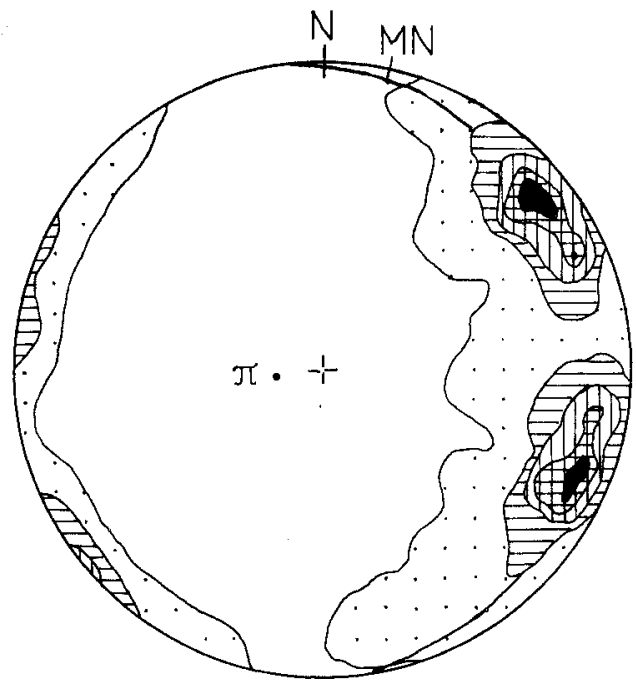

FIG. 2a - A contoured, equal-area, stereographic projection of the Mc. Partlan Synform using 215 poles to $S_{1}$. The contours are at $0-3$ $6-9-12 \%$. The $\tau$ T axis is $77^{\circ}$ to $260^{\circ}$.

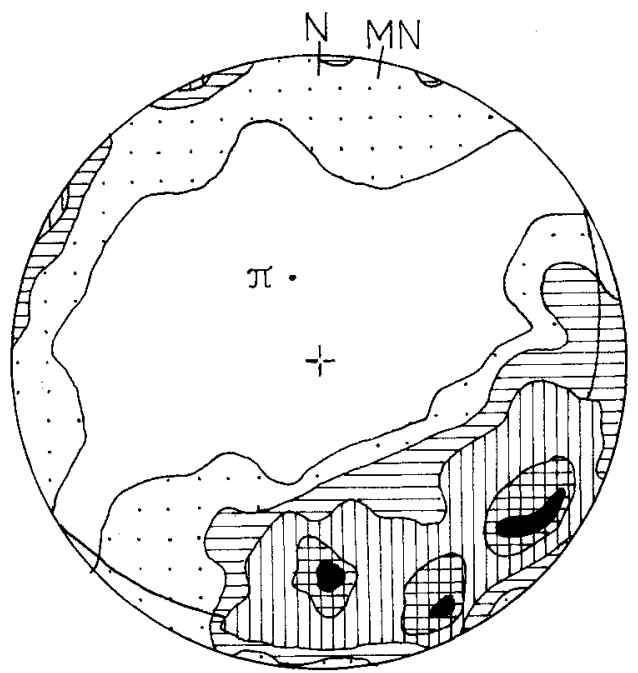

FIG. 2b.- A contoured, equal-area, stereographic projection of the Sentinels Antiform using 220 poles to $\mathrm{S}_{1}$ and $\mathrm{S}_{0}$. The contours are at $0-1-3-5-7 \%$. The $\pi$ axis is $77^{\circ}$ to $331^{\circ}$

$3 \mathrm{~cm})$ fracture. In micaceous quartzites and phyllites, $\mathrm{S}_{3}$ is a crenulation cleavage, with associated $\mathrm{L}_{3}$ crumple lineations. The nature of the crenulation cleavage is somewhat variable. One type consists of a spaced fracture (up to $2 \mathrm{~cm}$ ) with, at one extreme, only slight crenulation of the microlithon to, at the other extreme, a tightly folded microlithon between the fractures. Alternatively, $S_{3}$ may be the axial surface to sma11, open to tight, crumple folds of wavelength $1 \mathrm{~mm}$ to $2 \mathrm{~cm}$, which have no associated fracture. The most intense and most consistently developed $s_{3}$ occurs in phyllites. In the latter rocks differentiated crenulation cleavage (plate 4 ) is often developed and earlier foliations are difficult to recognize, due to their transposition into the $S_{3}$ direction.

\section{LATER STRUCTURES}

The $S_{3}$ cleavage has locally been folded by close $F_{4}$ minor folds with an associated weak crenulation cleavage of average orientation $296 / 68^{\circ} \mathrm{N}$. $F_{4}$ folds are best developed in micaceous quartzite and phyllite on the SW limb of the Mc. Partlan Synform, but they occur sporadically in these rock types throughout the area. No $F_{4}$ folds have been observed in quartzites. 


\section{S.J. Williams}

Later folds include $F_{5}$ kink bands, chevron kinks and conjugate kinks, and 1arger scale, open, concentric folds in more thickly layered rocks. The $\mathrm{F}_{5} \mathrm{kinks}$ have an average axial surface orientation of $250 / 70^{\circ}$ SSE. A broad, open refold of the Mc. Partlan Synform has an axial surface with this orientation and is probably a major $\mathrm{F}_{5}$ fold. Another, later, set of kink folds $\left(\mathrm{F}_{6}\right)$ has an average axial surface orientation of $008 / 60^{\circ} \mathrm{E}$

\section{METAMORPHISM}

The quartzite-phyllite assemblage of the Mc. Partlan Pass - Sentinels area is mineralogically relatively simple. In phylites muscovite, a pale-green iron-rich variety, varies from $40 \%$ to $90 \%$ of the total rock. Chlorite is nearly always present, but is usually only a minor component $(\leqslant 10 \%)$. Some pyrite in minor to accessory amounts may alwo be present. The micaceous quartzites are composed of quartz $(60 \%-90 \%$, muscovite $(5 \%-35 \%)$ and, in some cases, chlorite $(\leqslant 5 \%)$. Plagioclase, of composition $\mathrm{An}_{4}$ to $\mathrm{An}_{12}$, is sometimes present as a minor component $(\leqslant 5 \%)$. Accessory minerals include tourmaline, zircon, pyrite, microcline, apatite and rutile.

Chemical analyses of selected examples are shown on table 1. The analysed samples have been plotted on an $A^{\prime} \mathrm{KF}$ facies diagram (fig. 3), which indicates the assemblage belongs to the lower greenschist facies of metamorphism (Turner and Verhoogen 1960, p.534). The possible range of conditions of metamorphism for this assemblage is: temperature $200^{\circ} \mathrm{C}$ to $350^{\circ} \mathrm{C}$ and pressure $10^{2}$ $\mathrm{MPa}(1 \mathrm{~Kb})$ to $9 \times 10^{2} \mathrm{MPa}(9 \mathrm{~Kb})$. The intense foliation, associated with early deformation in many rocks in this area, indicates that metamorphism took place under conditions of high stress.

Although mineralogically simple, the pelitic rocks are texturally very complex. A study of crystallization with respect to various foliations $\left(S_{1}, S_{2}\right.$ and $\left.S_{3}\right)$ indicates a relatively complex history of mineral paragenesis, This is summarized in figure 4. Most of the new mineral development occurred during $\mathrm{D}_{1}$ and, to a lesser extent, during $\mathrm{D}_{2}$ There was also a rrominent static phase between $D_{1}$ and $D_{2}$, during which porphyrobtasts of chlorite and albite grew over $S_{1}$ in rocks with

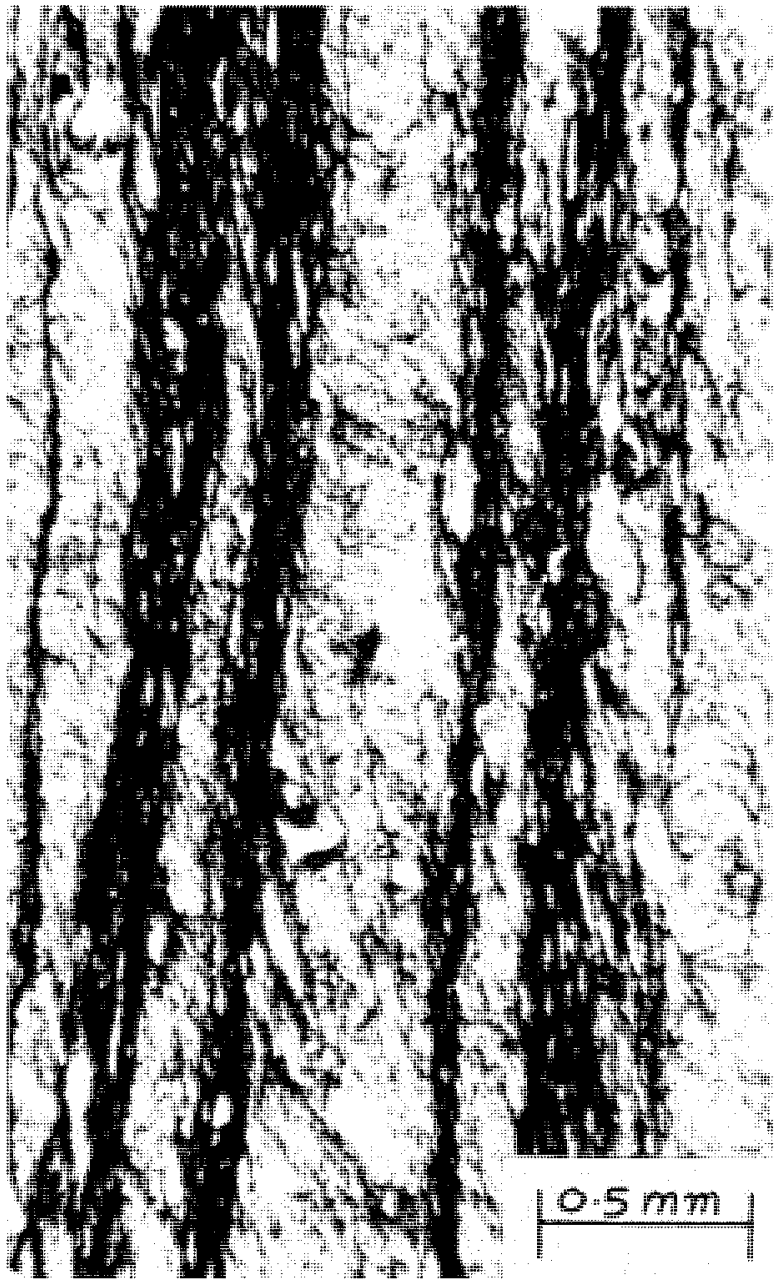

PLATE 4.-Differentiated $S_{3}$ crenulation cleavage in phyllite, with darker bands of mica growing parallel to the $S_{3}$ surface. suitable composition. In general only minor recrystallization accompanied the $D_{3}$ event and very little occurred after $D_{\text {.. }}$. 
There is no definite evidence from the present mineral assemblage as to when the metamorphic maximum was reached, if indeed there was such a climax. Some plagioclases have an oligoclase $\left(A n_{12}\right)$ composition which may indicate that the temperature did at some stage reach $350^{\circ} \mathrm{C}$ or higher. Some samples have idioblastic to subidioblastic chlorite flakes, which are post-S $S_{1}$ but pre-S2, and which appear to pseudomorph biotite flakes. It is possible that they formed from biotite during retrograde metamorphism, in which case the metamorphic maximum could be put at between $\mathrm{D}_{1}$ and $\mathrm{D}_{2}$, when biotite grade was reached. However this idea is speculative since no remnant biotites have been found.

The concept that retrograde metamorphism has occurred may be supported by the fact that the dominant muscovite in all specimens subject to X.R.D, analysis to 3T rather than 2M. Certainly, the multifoliated nature of many of these rocks would have made them particularly susceptible to retrograde effects, due to the ease of penetration, on all scales, of aqueous fluids.

TABLE 1

CHEMICAL ANALYSES OF PRECAMBRIAN METAMORPHIC ROCKS FROM THE MC PARTLAN PASS - SENTINELS AREA

\begin{tabular}{|c|c|c|c|c|c|c|c|}
\hline & 1 & 2 & 3 & 4 & 5 & 6 & 7 \\
\hline $\mathrm{SiO}_{2}$ & 60.16 & 66.24 & 69.51 & 73.89 & 79.60 & 84.07 & 87.66 \\
\hline $\mathrm{Al}_{2} \mathrm{O}_{3}$ & 20.69 & 16.23 & 15.25 & 11.81 & 8.30 & 8.24 & 4.84 \\
\hline $\mathrm{Fe}_{2} \mathrm{O}_{3}$ & 0.00 & 1.66 & 1.24 & 0.71 & 0.18 & 0.00 & 0.24 \\
\hline $\mathrm{Fe} 0$ & 2.60 & 1.88 & 2.62 & 1.02 & 2.25 & 0.51 & 2.10 \\
\hline Mno & 0.00 & 0.00 & 0.00 & 0.00 & 0.00 & 0.00 & 0.00 \\
\hline $\mathrm{TiO}_{2}$ & 0.85 & 0.65 & 0.70 & 0.29 & 0.27 & 0.28 & 0.49 \\
\hline $\mathrm{P}_{2} \mathrm{O}_{5}$ & 0.07 & 0.03 & 0.00 & 0.05 & 0.01 & 0.02 & 0.01 \\
\hline $\mathrm{CaO}$ & 0.01 & 0.01 & 0.01 & 0.03 & 0.01 & 0.00 & 0.01 \\
\hline Mg0 & 4.85 & 1.47 & 1.42 & 4.22 & 5.20 & 1.14 & 1.40 \\
\hline $\mathrm{Na}_{2} \mathrm{O}$ & 0.52 & 0.25 & 0.40 & 0.30 & 0.11 & 0.82 & 0.25 \\
\hline $\mathrm{K}_{2} \mathrm{O}$ & 5.32 & 3.91 & 3.45 & 3.58 & 1.17 & 3.72 & 1.27 \\
\hline Ignition Loss & 4.19 & 6.78 & 4.70 & 2.83 & 2.69 & 1.74 & 1.50 \\
\hline TOTAL & 99.26 & 99.11 & 99.30 & 98.73 & 99.79 & 100.54 & 99.77 \\
\hline
\end{tabular}

Chemical analyses of selected phyllites and micaceous quartzites from the Mc. Partlan Pass - Sentinels area. The numbers 1 to 7 refer respectively to specimens 40955, 40970, 40988, 40960, 40976, 40959, 40999, which are kept at the Ceology Department, University of Tasmania.

\section{DISCUSSION AND CONCLUSIONS}

Inhomogeneous deformation is evident during $D_{1}$ since micaceous rocks have a penetrative $S_{1}$ foliation developed, but the thicker, more competent, quartzjte sequences have no foliation, or only a weak foliation. The inhomogereity of deformation may be due to local variations in the overall Dl stress-field, but there seems to be no doubt that lithological differences have played a major role. Fl axial surfaces were rotated into near alignment with those of $F_{2}$ due to the near isoclinal nature of the latter folds. $\quad F_{2}$ folds are almost coplanar with the earlier folds.

The major period of metamorphism started with $\left.{ }^{1}\right]$ and continued until the end of $\mathrm{D}_{2}$. Metamorphism was triggered by the onset of the first deformation event, during which micas were formed from pre-existing sedimentary minerals. Such reactions would have involved the release of volatiles, which would in turn affect the style of deformation by markedly increasing the creep rate (Holland and Lambert 1969). Following 


\section{S.J.Williams}

the $D_{2}$ event there was probably a considerable time gap before the onset of the third deformation event, which produced the dominant folds in the area, but which was accompanied by only minor crystallization.

Cambrian quartzose conglomerates, sandstones and siltstones (Corbett 1970), to the immediate east of the Precambrian metamorphic rocks discussed herein, have two distinct sets of folds developed, which can be correlated, on the basis of orientation, with $F_{5}$ and $F_{6}$. This indicates a Palaeozoic age for these events. The conglomerate beds, within the Cambrian sequence contain pebbles and cobbles of micaceous quartzite with $S_{3}$ crenulation cleavage and $\mathrm{L}_{3}$ crumple lineations developed. These structures are not present in the bulk of the rock and so $D_{3}$, as well as the earlier $D_{1}$ and $D_{2}$ events, probably a Precambrian event. $\mathrm{D}_{4}$ may be a late Precambrian, or early Palaeozoic event.

Corbett (1970) regarded the metaconglomerate unit as either Cambrian or Precambrian. This unit has been found to contain all the early structures, including $S_{1}, S_{2}$ and $S_{3}$, of the metamorphosed Precambrian rocks to the south and west. It is thus regarded as being Precambrian in age.

Events $D_{1}$ and $D_{4}$ can probably be correlated with $D_{1}$ to $D_{4}^{4}$ in the Frankland and Wilmot Ranges (Boulter 1974). Correlation of this sequence with published structural sequences from elsewhere in the Older Precambrian of Tasmania, can be found in Table 1 of Boulter (1974)

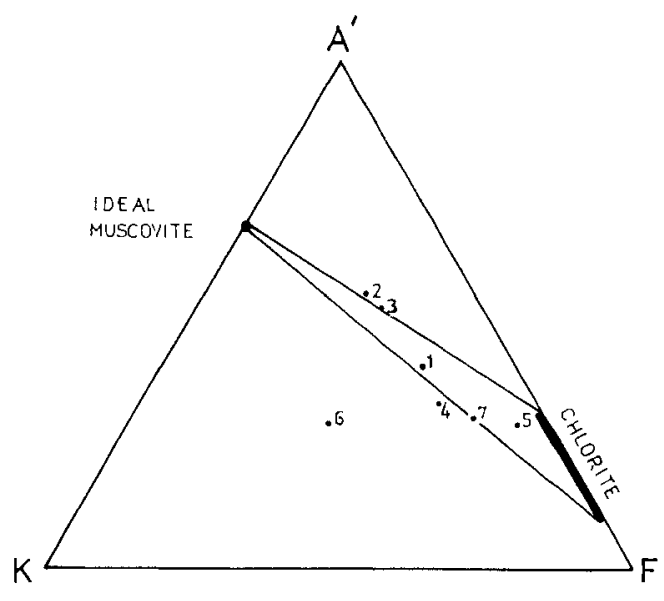

FIG. 3. - An A'KF facies diagram for selected phyllites and micaceous quartzites from the Mc. PartlanPass-Sentinels area.

$$
\begin{aligned}
A^{\prime}= & {\left[\mathrm{Al}_{2} \mathrm{O}_{3}\right]+\left[\mathrm{Fe}_{2} \mathrm{O}_{3}\right]-\left(\left[\mathrm{Na}_{2} \mathrm{O}\right]\right.} \\
& \left.+\left[\mathrm{K}_{2} \mathrm{O}\right]+[\mathrm{CaO}]\right) \\
K= & {\left[\mathrm{K}_{2} \mathrm{O}\right] } \\
\mathrm{F}= & {[\mathrm{FeO}]+[\mathrm{MgO}]+[\mathrm{MnO}] }
\end{aligned}
$$

No specific corrections have been made. Muscovite and chlorite have not been analysed separately and their position on the plot has been taken from Turner and Verhoogen (1960, p.537) and Winkler (1967, p.61).

The numbers refer to the same specimens as in Table 1.

\section{ACKNOWLEDGEMENTS}

The author gratefully achnowledges the guidance and encouragement of $\mathrm{Mr} . \mathrm{C}$. Boulter and members of the staff of the Geology Department, University of Tasmania. Many helpful discussions were held with $\mathrm{Mr}$. S. Cox, which were much appreciated. The co-operation of the HydroElectric Commission, and in particular the Mc. Partlan

\begin{tabular}{|c|c|c|c|c|c|c|c|}
\hline $\begin{array}{l}\text { DEFORMATION } \\
\text { PHASE }\end{array}$ & \multicolumn{3}{|c|}{$\mathrm{D}_{1}$} & \multicolumn{2}{|c|}{$\mathrm{D}_{2}$} & \multicolumn{2}{|c|}{$D_{3}$} \\
\hline 5 SURFACE & \multicolumn{3}{|c|}{$\mathrm{S}_{1}$} & \multicolumn{2}{|c|}{52} & \multicolumn{2}{|c|}{$\mathrm{S}_{3}$} \\
\hline MINERAL $\downarrow$ & PRE & SYN & POST & SYN & POST & SYN & POST \\
\hline \multicolumn{8}{|l|}{ QUARTZ } \\
\hline \multicolumn{8}{|l|}{ MUSCOVITE } \\
\hline CHLORITE & & & & & - & & \\
\hline ALBITE & & & & & & & \\
\hline
\end{tabular}
Pass engineer, Mr. S. Li, is
gratefully acknowledge. I would also like to thank Mrs. K. Osbourne, who typed the

FIG. 4.- The chronological relationship between metamorphic crystallization and S-surfaces in pelitic rocks from the Mc. Partlan Pass-Sentinels area. 


\section{REFERENCES}

Boulter, C.A., 1974: Structural sequence in the metamorphosed Precambrian rocks of the Frankland and Wilmot Ranges, south-western Tasmania. Pap. Proe. R. Soc. Tasm. , 107, 105-115.

Bowen, E.A. and Maclean, C.J. 1971: Structure of the Precambrian rocks of the Davey River area, south-western Tasmania. Pap. Proc. R. Soc. Tasm., 105, 97-104.

Corbett, K.D., 1970: Sedimentology of an upper Cambrian Flysch paralic seauence (Denison Group) of the Denison Range, southwesi Tasmania. Ph. D. Thesis, university of Tasmania, 207pp. (unpublished).

Holl and, J.G. and Lambert, R.St.J., 1969: Structural regimes and metamorphic facies. Tectonophysics, $7(3), 197-217$.

Powell, C. McA., 1969: Polyphase folding in Precambrian low-grade metamorphic rocks, middle Gordon River, south-western Tasmania. Pap. Proc. R. Soe. Tasm., 103, 47-51.

Ramsay, J.G. 1962: Interference patterns produced by the superposition of folds of similar type. J. Geol., 70, 466-481.

Turner, F.J. and Verhoogen, J., 1960: IGNEOUS AND METAMORPHIC PETROLOGY, 2nd ed. McGraw Hi11, New York., 694 pp.

Winkler, H.C.F., 1967. PETROGENESIS OF METAMORPHTC ROCKS. 2nd ed. Springer, Rerlin, $218 \mathrm{pp}$. 